\title{
Extensive cervical lymphadenitis mimicking bacterial adenitis as the first presentation of Kawasaki disease
}

\author{
Extensa linfadenite cervical mimetizando adenite bacteriana \\ como primeira manifestação da doença de Kawasaki
}

\author{
Felipe de Souza Rossi ${ }^{1}$, Marco Felipe Castro da Silva ${ }^{2}$, Kátia Tomie Kozu ${ }^{2}$, Luís Fernando Aranha Camargo ${ }^{1}$, \\ Flávia Feijó Panico Rossi ${ }^{1}$, Clovis Artur Silva ${ }^{2}$, Lúcia Maria de Arruda Campos ${ }^{1,2}$
}

\begin{abstract}
Cervical adenitis $>1.5 \mathrm{~cm}$ in diameter is the less frequently observed criteria in patients with Kawasaki disease and it is usually found in association with other symptoms during the acute phase. Moreover, the finding of fever and lymphadenitis with intense local signs of inflammation and phlegmon is rarely seen as the initial manifestation of Kawasaki disease. We report the case of a 7-year-old boy who had cervical lymphadenitis with adjacent cellulitis and phlegmon mimicking bacterial adenitis as the first presentation of Kawasaki disease. The patient had fever, cervical lymphadenitis with adjacent cellulitis, and severe headache. Cefadroxil was prescribed based on the clinical diagnosis of bacterial adenitis. Because he remained febrile and phlogistic signs worsened, after 1 day of hospitalization, antibiotics were administrated intravenously (ceftriaxone and oxacillin). The computed tomography of the neck showed primary infectious/ inflammatory process. On the fourth day, the patient had dry and scaly lips, and treatment with oxacillin was replaced by clindamycin because the patient was still febrile. On the ninth day, he presented non-exudative bilateral conjunctival injection. On the tenth day of febrile disease, a rash appeared on his trunk, hands and feet. Patient's symptoms resolved after intravenous administration of immunoglobulin $(2 \mathrm{~g} / \mathrm{kg} / \mathrm{dose})$, and he was discharged 2 days later. On the 14th day, the patient had lamellar desquamation of fingers. Kawasaki disease should be considered as a differential diagnosis in children with febrile cervical lymphadenitis unresponsive to empiric antibiotics even if they have adjacent cellulitis and phlegmon.
\end{abstract}

Keywords: Mucocutaneous lymph node syndrome; Child; Lymphadenitis; Cellulitis; Diagnosis, differential; Case reports

\section{RESUMO}

Adenite cervical $>1,5 \mathrm{~cm}$ é 0 critério menos frequentemente observado em pacientes com doença de Kawasaki e manifesta-se habitualmente em associação com os demais sintomas da fase aguda. Entretanto, linfadenite febril isolada com intensos sinais flogísticos e flegmão é raramente observada como primeira manifestação da doença de Kawasaki. Assim, relatou-se aqui um caso de uma criança que apresentou linfadenite cervical com celulite adjacente e flegmão mimetizando adenite bacteriana como primeira manifestação da doença de Kawasaki. Paciente previamente hígido, 7 anos, masculino, iniciou quadro de febre, adenite cervical com celulite adjacente e cefaleia intensa, sendo prescrita cefadroxila devido ao diagnóstico clínico de linfadenite bacteriana. Por se manter febril e com piora dos sinais flogísticos, após 1 dia foi internado para receber antibioticoterapia endovenosa (oxacilina e ceftriaxona). Tomografia computadorizada da região cervical mostrou processo infeccioso/inflamatório primário. No quarto dia, apresentou lábios ressecados e descamativos, sendo a oxacilina substituída por clindamicina devido à persistência da febre $\mathrm{e}$ sinais flogísticos. No nono dia, iniciou hiperemia ocular não exsudativa. No décimo dia de febre, apresentou exantema em tronco, membros, mãos e pés. Recebeu gamaglobulina endovenosa $(2 \mathrm{~g} / \mathrm{kg} / \mathrm{dose})$, evoluiu com resolução dos sintomas e, após 2 dias, recebeu alta hospitalar. No $14^{\circ}$ dia, apresentou descamação lamelar dos dedos das mãos. Portanto, doença de Kawasaki deve ser considerada no diagnóstico diferencial das linfadenites cervicais febris na infância não responsivas à antibioticoterapia empírica, mesmo que esteja presentes celulite adjacente e flegmão.

Descritores: Síndrome de linfonodos mucocutâneos; Criança; Linfadenite; Celulite; Diagnóstico diferencial; Relatos de casos

\footnotetext{
Hospital Israelita Albert Einstein, São Paulo, SP, Brazil.

${ }^{2}$ Instituto da Criança, Hospital das Clínicas, Faculdade de Medicina, Universidade de São Paulo, São Paulo, SP, Brazil.

Corresponding author: Lúcia Maria de Arruda Campos - Avenida Éneas de Carvalho Aguiar, 647 - Zip code: 05403-000 - São Paulo, SP, Brazil - Phone: (55 11) $3814-8481$ E-mail: lucia@arrudacampos.com

Received on: Sep 27, 2013 - Accepted on: Aug 29, 2014

DOI: 10.1590/S1679-45082015RC2987
} 


\section{INTRODUCTION}

Kawasaki disease $(\mathrm{KD})$ is a multisystemic severe vasculitis of medium- and small-sized vessels. This acute febrile illness might have several inflammatory manifestations, such as cervical adenitis. ${ }^{(1)}$ Of note, unilateral cervical adenitis measuring $>1.5 \mathrm{~cm}$ in diameter is the less frequently observed criteria in $\mathrm{KD}$ patients and it is usually presented in association with other symptoms at disease onset. ${ }^{(2)}$

The finding of fever and lymphadenitis with intense local signs of inflammation and phlegmon formation is rarely described as the initial manifestation of $\mathrm{KD},{ }^{(3)}$ and it was previously misdiagnosed as bacterial adenitis (BA). ${ }^{(4)}$

We report a case of a 7-year-old boy who had cervical lymphadenitis with adjacent cellulitis and phlegmon mimicking $\mathrm{BA}$ as the first presentation of $\mathrm{KD}$.

\section{CASE REPORT}

A previously healthy 7-year-old Caucasian boy was admitted to our service with fever $\left(39\right.$ to $\left.40^{\circ} \mathrm{C}\right)$, cervical lymphadenitis with adjacent cellulitis (Figure 1) and severe headache. Cefadroxil was prescribed because of the clinical diagnosis of BA. The next day, he was admitted to Hospital Israelita Albert Einstein to receive intravenous antibiotics (oxacillin and ceftriaxone) in consequence of the persistent fever with worsening of the surrounding pain and inflammation. Laboratory findings showed hemoglobin $(\mathrm{Hb}) 10.2 \mathrm{~g} / \mathrm{dL}$, white blood cell count (WBC) $11,640 / \mathrm{mm}^{3}$ (77\% neutrophils, $12 \%$ lymphocytes, 9\% monocytes, $1 \%$ eosinophils, and $1 \%$ basophils), platelets $301,000 / \mathrm{mm}^{3}$, C-reactive protein (CRP) $217.4 \mathrm{mg} / \mathrm{dL}$ (normal 0-0.3), aspartate aminotransferase 28U/L (normal 15-40U/L), alanine aminotransferase 20U/L (normal 10-35U/L), amylase 58U/L (normal 0-110U/L) and antistreptolysin O $143 \mathrm{IU} / \mathrm{mL}$ (normal 0-200IU/mL). Serological tests for cytomegalovirus, toxoplasmosis, mononucleosis and bartonellosis were negative. Cervical computed tomography (CT) revealed right cervical lymph nodes increased in number and size, measuring up to $2.1 \mathrm{~cm}$, without signs of liquefaction, besides densification and thickening of the regional soft tissues on the face and neck, strongly suggestive of extensive cellulitis and phlegmon. Cervical collections were not observed. On the fourth day, he had dry and scaly lips (Figure 2), and oxacillin was replaced by clindamycin since the patient was still febrile with persistent inflammatory signs. On the ninth day, he presented non-exudative bilateral conjunctival injection (Figure 3). The ophthalmic examination revealed bilateral anterior uveitis and echocardiography was normal. After 10 days of febrile disease, a discrete maculopapular rash appeared on patient's trunk, hands and feet, which fulfilled criteria for KD..$^{(1,5)}$ We administrated intravenous immunoglobulin $(2 \mathrm{mg} / \mathrm{kg})$ and an improvement of the inflammatory manifestations was seen. Two days later, he was discharged, and we prescribed oral cefuroxime and aspirin $(3.7 \mathrm{mg} / \mathrm{kg} /$ day $)$, corticosteroid and mydriatic eye drops. On the 14th day, he had lamellar desquamation of the fingers, which lasted for 10 days (Figure 4). At that moment, laboratory tests revealed: $\mathrm{Hb} 11.5 \mathrm{~g} / \mathrm{dL}, \mathrm{WBC}$ 5,400 cells $/ \mathrm{mm}^{3}$ (51\% neutrophils, 34\% lymphocytes, $11 \%$ monocytes, $3 \%$ eosinophils, and $1 \%$ basophils), platelets $280.000 / \mathrm{mm}^{3}$ and CRP $1.7 \mathrm{mg} / \mathrm{dL}$. Echocardiogram remained normal between 10 and 45 days of follow-up after symptoms resolution.

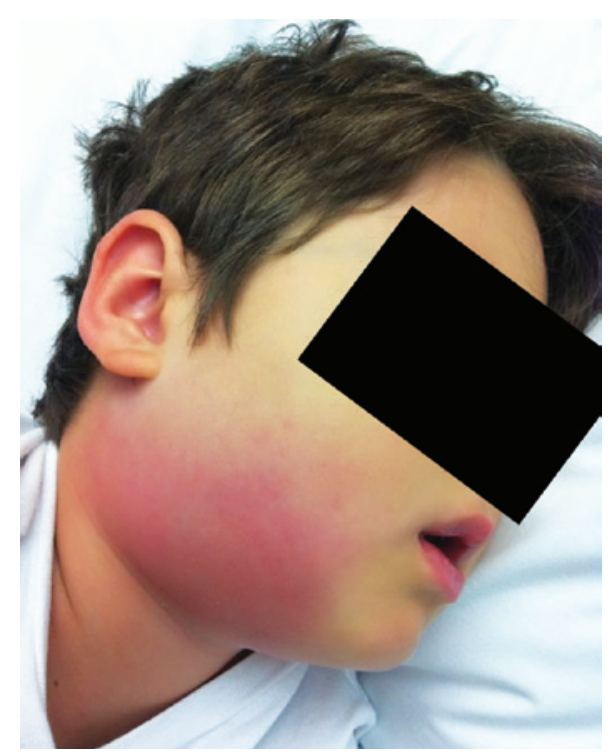

Figure 1. Cervical lymphadenitis with adjacent cellulitis initially seen in the described Kawasaki disease patient

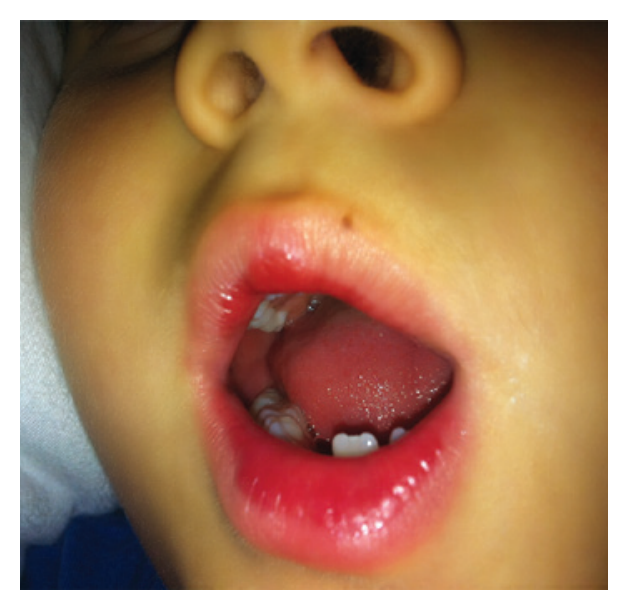

Figure 2. Dry and injected lips 


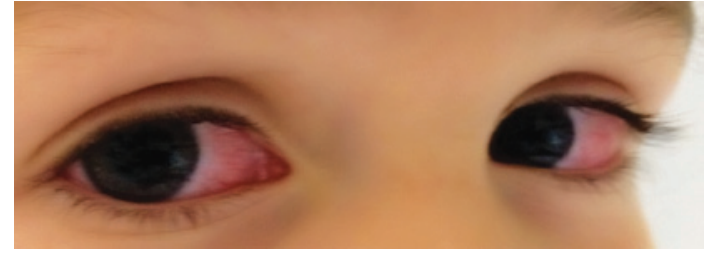

Figure 3. Non-exudative bilateral conjunctival injection

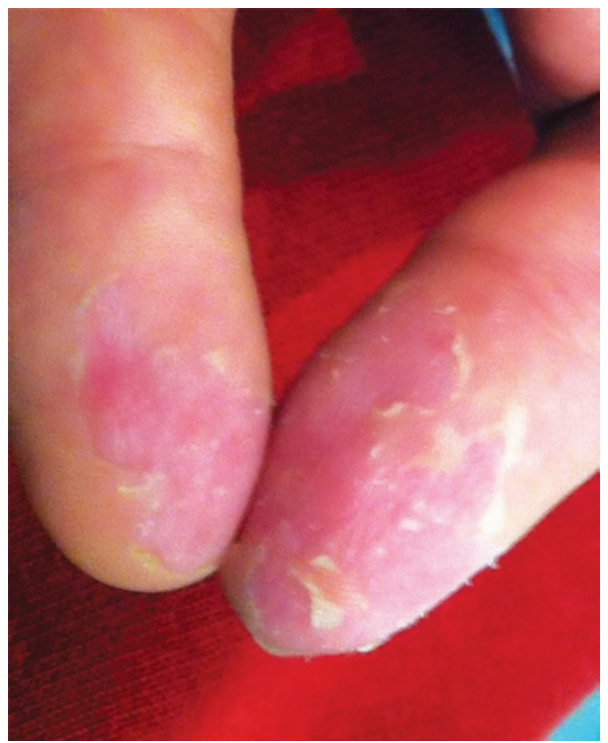

Figure 4. Lamellar desquamation of the fingers

\section{DISCUSSION}

To our knowledge, only one case of cervical adenitis with phlegmon formation, as the first manifestation of $\mathrm{KD}$, has been described. ${ }^{(3)}$ We are reporting the second case in the medical literature.

$\mathrm{KD}$ is slightly more common in boys than in girls (male-to-female ratio of 1.5-1.8:1) and the majority of the affected patients are aged 6 months to 5 years old. ${ }^{(1)}$ Only about $15 \%$ of the patients are older than 5 years, ${ }^{(6)}$ such as the present case. Moreover, incomplete KD has been more frequently reported in patients older than 5 years or younger than 12 months old. The subsequent delay to begin proper treatment in these cases increases the risk of coronary involvement, since its efficacy is higher when used within the first 10 days of illness. ${ }^{(7)}$ Regarding ethnicity, although KD is remarkably more frequent in Asian descent, which suggest the existence of a genetic predisposition, this disease is found worldwide in a small but rising incidence. ${ }^{(7)}$

The diagnosis of KD is based on clinical features, and there is no clinical or laboratory pathognomonic findings. ${ }^{(1)}$ Cervical lymphadenopathy is considered the less common criteria found in patients with $\mathrm{KD}$, which is described in about $50 \%$ of cases, while others signs such as non exudative conjunctival injection, oropharynx mucosa abnormalities, polymorphous rash and extremities changes occur in approximately $90 \%$ of classic KD. ${ }^{(4)}$

Furthermore, cervical adenitis is normally seen associated with other acute phase symptoms. In a recent review of the literature, isolated cervical adenitis and fever were reported in 57 patients as the first finding of $\mathrm{KD}^{(3)}$ Except for transient nonspecific lip dryness, our patient had persistent febrile adenitis as the only involvement of $\mathrm{KD}$ up to the ninth day of disease. In addition, the presence of adjacent cellulitis in the neck reinforced the importance of disregard the possibility of infectious causes, such as bacterial and viral illnesses, toxoplasmosis and cat scratch disease. The presence of phlegmon is quite rare in KD and was found only in one patient among the cases described by Kanegaye et al.(3)

An interesting point was the severe headache presented by our patient. Despite headache be a common finding during febrile episodes in children, especially with higher temperatures, in our case this symptom might have been due to aseptic meningitis, what is seen in approximately one-third of KD patients. In children, it usually manifests as irritability. ${ }^{(8)}$

A question that could be raised is whether the lymphadenitis seen at presentation of this case was in fact a BA acting as a trigger of $\mathrm{KD}$. Reports in the literature describe that up to $33 \%$ of $\mathrm{KD}$ patients have at least one concurrent infection at disease onset, which could be considered as an environmental trigger of the illness. ${ }^{(7,9)}$ The similarities in clinical and biochemical presentation of both KD, staphylococcal and streptococcal toxin mediated illnesses suggest the possibility of bacterial involvement in the disease etiology in genetic susceptible subjects. ${ }^{(9)}$

Radiographic studies might be of utmost importance to differentiate $\mathrm{KD}$ versus $\mathrm{BA}$. A previous study performed cervical $\mathrm{CT}$ in 11 of $57 \mathrm{KD}$ patients with lymphadenopathy as first presentation versus 39 of 78 patients with BA. Solid nodes were found in $91 \%$ of the former group, whereas this finding was showed in only $28 \%$ of the second group $(p=0.003){ }^{(3)}$ In contrast, when the authors investigated the existence of phlegmon, this inflammation was present in $14 \mathrm{BA}$ subjects, but in only one KD patient. (3) In our case, the same rare characteristic was confirmed in the cervical CT performed.

The presence of cervical adenitis without abscess formation unresponsive to a broad-spectrum antibiotic therapy alerts the need of seeking differential diagnoses. In our patient the diagnosis of $\mathrm{KD}$ was confirmed by further fulfillment of KD's criteria. In fact, the majority of previous studies with KD patients with 
lymphadenitis reported as their initial presentation the administration of antibacterial agents as the first line treatment, but with poor response. ${ }^{(3,4)}$ In our case the cellulitis was completely resolved just after the infusion of intravenous immunoglobulin, which is considered the recommended treatment for primary KD. ${ }^{(10,11)}$

\section{CONCLUSION}

Kawasaki disease should be considered as the differential diagnosis for febrile cervical lymphadenitis in children who are unresponsive to initial empiric antibiotics, even if they have adjacent cellulitis and phlegmon.

\section{REFERENCES}

1. Kawasaki T, Kosaki F, Okawa S, Shigematsu I, Yanagawa H. A new infantile acute febrile mucocutaneous lymph node syndrome (MLNS) prevailing in Japan. Pediatrics. 1974;54(3):271-6.

2. Falcini F, Capannini S, Rigante D. Kawasaki syndrome: an intriguing disease with numerous unsolved dilemmas. Pediatr Rheumatol Online J. 2011;9:17.
3. Kanegaye JT, van Cott E, Tremoulet AH, Salgado A, Shimizu C, Kruk P, et al. Lymph-node-first presentation of Kawasaki disease compared with bacterial cervical adenitis and typical Kawasaki disease. J Pediatr. 2013;162(6):1259-63.

4. Kao HT, Huang YC, Lin TY. Kawasaki disease presenting as cervical lymphadenitis or deep neck infection. Otolaryngol Head Neck Surg. 2001; 124(4):468-70.

5. Ozen S, Ruperto N, Dillon MJ, Bagga A, Barron K, Davin JC, et al. EULAR/PReS endorsed consensus criteria for the classification of childhood vasculitides. Ann Rheum Dis. 2006;65(7):936-41.

6. Burns JC, Kushner HI, Bastian JF, Shike H, Shimizu C, Matsubara T, et al. Kawasaki disease: A brief history. Pediatrics. 2000;106(2):E27. Review.

7. Jamieson N, Singh-Grewal D. Kawasaki Disease: A Clinician's Update. Int J Pediatr. 2013;2013:645391. Review.

8. Dengler LD, Capparelli EV, Bastian JF, Bradley DJ, Glode MP, Santa S, et al Cerebrospinal fluid profile in patients with acute Kawasaki disease. Pediatr Infect Dis J. 1998;17(6):478-81.

9. Benseler SM, McCrindle BW, Silverman ED, Tyrrell PN, Wong J, Yeung RS. Infections and Kawasaki disease: implications for coronary artery outcome. Pediatrics. 2005;116(6):e760-6.

10. Tse SM, Silverman ED, McCrindle BW, Yeung RS. Early treatment with intravenous immunoglobulin in patients with Kawasaki disease. J Pediatr. 2002;140(4):450-5.

11. Sánchez-Manubens J, Bou R, Anton J. Diagnosis and classification of Kawasaki disease. J Autoimmun. 2014;48-49:113-7. Review. 